
\title{
Journal of Management
}

Middle Managers' Strategic Role in the Corporate Entrepreneurial Process: Attention-Based Effects

Charlotte R. Ren and Chao Guo

Journal of Management published online 22 February 2011

DOI: $10.1177 / 0149206310397769$

The online version of this article can be found at:

http:/jom.sagepub.com/content/early/2011/02/21/0149206310397769

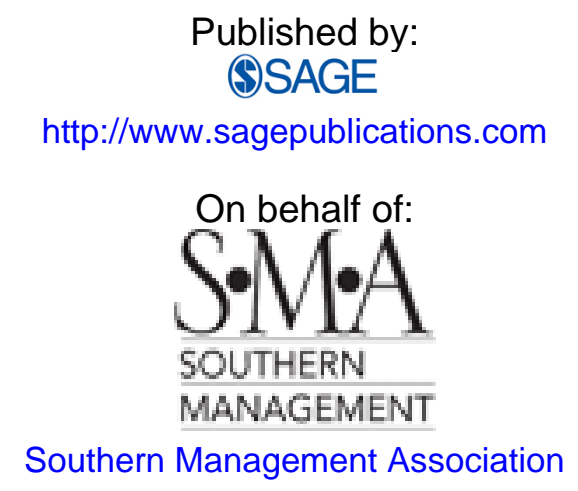

Additional services and information for Journal of Management can be found at:

Email Alerts: http:/jom.sagepub.com/cgi/alerts

Subscriptions: http://jom.sagepub.com/subscriptions

Reprints: http://www.sagepub.com/journalsReprints.nav

Permissions: http://www.sagepub.com/journalsPermissions.nav 
Journal of Management

Vol. XX No. X, Month XXXX xx-xx

DOI: $10.1177 / 0149206310397769$

(C) The Author(s) 2011

Reprints and permission: http://www.

sagepub.com/journalsPermissions.nav

\title{
Middle Managers' Strategic Role in the Corporate Entrepreneurial Process: Attention-Based Effects
}

\author{
Charlotte R. Ren \\ Purdue University \\ Chao Guo \\ University of Georgia
}

This article examines the strategic role of middle managers in the corporate entrepreneurial process from an attention-based perspective. By integrating literatures from multiple disciplines, the authors delineate the attention-based effects on how middle managers provide the impetus for different types of entrepreneurial opportunities (i.e., exploratory vs. exploitative initiatives). Specifically, middle managers, constrained by the attention structures of the firm, likely prescreen entrepreneurial opportunities from lower organizational levels and attend primarily to those that align with the strategic orientation of the firm. This tendency may be moderated by the presence of other players, middle managers' structural positions, and the availability of slack resources. Moreover, in their efforts to sell initiatives to top management, middle managers may leverage "policy windows"-patterned regularities and irregularities in and around the organization-to exploit existing attention structures to their advantage or perhaps to dismantle those structures.

Keywords: middle managers; corporate entrepreneurial process; exploratory versus exploitative opportunity; attention structures; policy windows

\footnotetext{
Acknowledgments: An earlier version of this article received the Inaugural IDEA award in the Research Promise category from the Entrepreneurship Division of the Academy of Management in 2008. We are grateful to Arnie Cooper, Steve Floyd, Tim Folta, Hal Rainey, Dan Schendel, and Olav Sorenson for their valuable feedback. We would also like to thank Jeremy Short and two anonymous reviewers for their helpful comments and suggestions. Errors and omissions remain our responsibility.
}

Corresponding author: Charlotte Ren, Krannert School of Management, Purdue University, 403 West State Street, West Lafayette, IN 47907, USA

Email: rren@purdue.edu 
In recent years, entrepreneurship scholars have advanced theory building in the field. One important outcome of this effort is the opportunity-based perspective, which has encouraged the field of entrepreneurship research to consider the discovery and exploitation of entrepreneurial opportunities (Shane \& Venkataraman, 2000). Meanwhile, strategic management scholars have emphasized the importance of strategic entrepreneurship as a means for firms to compete and succeed in dynamic markets. Leading advocates of this approach suggest that strategic entrepreneurship integrates entrepreneurial (i.e., opportunity-seeking) and strategic (i.e., advantage-seeking) perspectives to design and implement wealth-creating entrepreneurial strategies (Hitt, Ireland, Camp, \& Sexton, 2001, 2002).

At the heart of the intersection between entrepreneurship and strategic management is corporate entrepreneurship, that is, entrepreneurship inside a firm. Corporate entrepreneurship is increasingly recognized as a contributor to competitive advantage and strategic renewal (Barringer \& Bluedorn, 1999; Covin \& Miles, 1999; Guth \& Ginsberg, 1990). Yet it represents a fundamental challenge for established firms: How can they manage the conflict between the new and the old (Dess, Ireland, Zahara, Floyd, Janney, \& Lane, 2003)? How can they engage in enough exploitation to ensure current viability but also enough exploration to ensure future viability (Levinthal \& March, 1993)? Achieving an appropriate balance between these two efforts is not easy. In particular, large, established firms tend to be more competent at exploiting opportunities closer to their existing businesses and competencies but less effective in developing exploratory or breakthrough innovations (Ahuja \& Lampert, 2001; Christensen, 2000; Utterback, 1994). They also oscillate between "creating the future" by pursuing exploratory opportunities and "protecting the core" by pursuing exploitative opportunities (Burgelman \& Välikangas, 2005; Wolpert, 2002).

Understanding and resolving this important challenge requires a more careful examination of the strategic role of middle managers in the corporate entrepreneurial process (Floyd $\&$ Wooldridge, 1992). A growing body of literature argues that middle managers are critical to corporate strategy formation: As champions of strategic alternatives, middle managers provide sponsorship or the impetus for new opportunities from lower organizational levels and make them accessible to top management. In so doing, they reshape the strategic thinking of top management and alter the firm's strategic course (Bower, 1970; Burgelman, 1983a, 1983b, 1983c; Dutton \& Ashford, 1993; Floyd \& Wooldridge, 1992, 1994, 1997; Hornsby, Kuratko, \& Zahra, 2002; Kanter, 1983). Notwithstanding its important insights, extant literature has yet to explore how middle managers' championing role plays out during different phases of the corporate entrepreneurial process, as well as the conditions that facilitate or hinder these roles. In particular, most literature ignores the influence of middle managers' limited attentional capacities (March \& Olsen, 1976; Simon, 1947) on the efficacy of their championing efforts. The implicit assumption appears to be that middle management champions have the capacity to attend to and evaluate every available opportunity.

Bounded by their limited attentional capacities though, middle managers cannot attend to all the entrepreneurial opportunities; rather, they notice some opportunities but must ignore others. Where middle managers focus their attention determines what they do. An organization could miss the chance to exploit an opportunity if that opportunity never appears on middle managers' radar screens. An organization also might pursue exploitative opportunities excessively and miss the next breakthrough innovation if middle managers' attention was never directed toward those exploratory ideas. Therefore, it is imperative to understand the 
process by which middle managers allocate their limited attentional focus to different entrepreneurial opportunities. Why and how do these managers choose to push some entrepreneurial opportunities and not others? In particular, in which circumstances do middle managers pay attention to exploratory rather than exploitative opportunities, and vice versa? To answer these questions, we draw on the attention-based perspective (March \& Olsen, 1976; Ocasio, 1997; Weick, 1979) and propose a two-phase model to explain how a firm's structures and context influence the entrepreneurial opportunities that middle managers first notice, sponsor, and then sell to top management.

Our work makes several important contributions to existing literature. First, joining the efforts to bring the middle management perspective into corporate entrepreneurship research, we identify two distinctive roles that middle managers play when they provide impetus for entrepreneurial initiatives: evaluating and selling. This distinction provides a more refined understanding of their championing role in the process of corporate entrepreneurship. Second, we distinguish two types of entrepreneurial opportunities, namely, exploratory and exploitative, according to their relatedness to core businesses and competences. Such a conceptualization enables us to develop insights that help resolve the fundamental challenge in corporate entrepreneurship of balancing the new and the old (Dess et al., 2003). Exploratory opportunities can take an organization in new strategic directions, so our examination of when and how middle managers champion exploratory opportunities offers a greater clarity and better understanding of middle managers' importance in strategy formation. Third, this study is among the first to investigate how the limited attentional capacities of middle managers affect their efforts to champion entrepreneurial opportunities. We argue that the efficacy of middle managers' initiative evaluator role is conditioned by their own capacity to pay attention to different opportunities that emerge from lower organizational levels; their initiative seller role is conditioned by their ability to get top managers to pay attention to such opportunities. We integrate literature from multiple disciplines to delineate the attention-based effects on how middle managers provide the impetus for exploratory versus exploitative opportunities. In the Discussion section, we detail the contributions of our model and its practical implications.

The rest of this article is organized as follows: We review prior literature regarding the strategic role of middle managers in the corporate entrepreneurial process and the building blocks of our model, including attention structures and policy windows. We then propose a two-phase conceptual framework that demonstrates how middle managers evaluate and sell entrepreneurial opportunities in an established firm. We conclude with a discussion of the contributions of the study and directions for further research.

\section{Theoretical Underpinnings}

\section{Middle Managers in Corporate Entrepreneurship}

Middle managers occupy positions between the strategic apex and the operating core of an organization (Mintzberg, 1989). Their job titles may include "general manager," "plant manager," "regional manager," and "divisional manager," among others. Since Bower's (1970) work, researchers have widely recognized the contribution of middle managers to corporate 
entrepreneurship. Two complementary views have emerged. First, middle managers make their contribution primarily through implementing strategic decisions by facilitating information flows between top managers and operating-level managers. They "endorse [corporate entrepreneurial] perspectives coming from top-level executives and 'sell' their valuecreating potential to the primary implementers - first-level managers and their direct reports" (Kuratko, Ireland, Covin, \& Hornsby, 2005: 705; see also Hornsby et al., 2002; King, Fowler, \& Zeithaml, 2001). Within this context, middle managers' entrepreneurial behavior is mainly top-down - induced by top management - and focused on developing innovations based on existing business and competence (Fulop, 1991).

Second, as our point of departure, another view links middle managers to corporate strategy formation (Burgelman, 1983a, 1983b, 1983c; Floyd \& Wooldridge, 1992, 1994, 1997, 1999). Burgelman (1983b) argues that the contribution of middle managers to corporate strategy formation results from their key role in autonomous strategic activities. Whereas frontline managers are deeply involved in the process of defining new business opportunities, middle managers are particularly important for managing the activities by which the new opportunities gain and maintain support in the organization, that is, the impetus process. This process is bottom up: Middle managers evaluate and sponsor strategic initiatives championed by frontline managers and then "sell" these initiatives to top management through strategic building and organizational championing activities.

Floyd and Wooldridge (1992) thus develop a typology of four middle management strategic roles: championing alternatives, synthesizing information, facilitating adaptability, and implementing deliberate strategy. Of particular relevance to the impetus process is the championing alternatives role, an upward, divergent form of influence that involves justifying and defining new programs, evaluating the merits of new proposals, searching for new opportunities, and proposing projects to top managers. Floyd and Wooldridge (1999) further maintain that middle managers contribute to firm capability development through three critical mechanisms or stages in the corporate entrepreneurial process: identifying entrepreneurial opportunities, developing entrepreneurial initiatives, and renewing organizational capabilities. These three stages cover both the definition and impetus processes. Floyd and Wooldridge consider middle management the locus of corporate entrepreneurship, though they do not delineate their exact roles in each stage of the corporate entrepreneurial process.

In line with Burgelman (1983b) and Floyd and Wooldridge (1992, 1999), we divide middle managers' championing role in the impetus process into two parts. First, middle managers evaluate the strategic merits of entrepreneurial initiatives emerging from lower organizational levels and assess their potential for future corporate growth. This evaluator role involves the decision to endorse an initiative or not, as well as how much support to offer (Kuratko et al., 2005). It also involves bouncing the idea off others to verify and assess its feasibility (Shi, Markoczy, \& Dess, 2009). Second, they gain top management's attention and support for an entrepreneurial initiative that may fall outside the organizational agenda. In this "seller" role, they reshape the strategic thinking of top management and get top management to modify existing corporate strategy to accommodate successful new initiatives (Burgelman, 1983a, 1983b). 


\section{Initiative Evaluation and the Notion of "Attention Structures"}

Prior literature provides a solid foundation for understanding the criteria that middle managers use to discover, evaluate, and sponsor potential entrepreneurial opportunities (e.g., Floyd \& Wooldridge, 1992, 1994, 1997, 1999; Kuratko et al., 2005). Burgelman (1983b) notes that because middle managers' career prospects depend on developing a good "batting average" of support for strategic projects, they evaluate proposals in the light of the reward and measurement systems that determine whether a particular initiative is worth supporting. Field data also suggest that early operational results largely determine whether middle managers will provide impetus to new initiatives (Burgelman \& Sayles, 1986; Noda \& Bower, 1996).

Although these studies improve our understanding of middle managers' choices among entrepreneurial initiatives, they appear to ignore an important factor: the problem of limited attention. With limited information-processing capabilities (March \& Olsen, 1976; Simon, 1947), middle managers cannot pay attention to all available initiatives; they notice some initiatives while ignoring others. So what influences the allocation of their attention in the process of evaluating initiatives? In which circumstances do middle managers pay attention to exploratory rather than exploitative initiatives, or vice versa? In an early effort to address the issue of attention in the context of organizational innovation, Van de Ven (1986) notes that managing attention is a central problem in innovation management because organizations are largely designed to focus on exploiting existing practices rather than paying attention to new ideas. The management of attention therefore should focus on channeling people's attention toward new opportunities. Following Van de Ven's argument, Angle (1989) suggests that the level of innovation in an organization increases with the presence of mechanisms for focusing managerial attention on changing conditions and emerging opportunities.

Ocasio (1997) also presents an attention-based view of the firm that provides more systematic insights into the management of attention. This attention-based view notes the influences of decision makers' limited attention capacity and organizational structural regularities. In particular, it emphasizes the role of "attention structures" (March \& Olsen, 1976), defined as "the social, economic, and cultural structures that govern the allocation of time, effort, and attentional focus of organizational decision makers in their decision-making activities" (Ocasio, 1997: 195). A firm's attention structures channel and distribute the limited attention of decision makers through the valuation and legitimization of issues and opportunities (Ocasio, 1997). For example, to the extent that attention structures are externally oriented, managers are more likely to notice latent opportunities in new markets and less likely to notice shadow options within existing markets (Barnett, 2008).

In keeping with the attention-based view, we can expect that as a firm's attention structures vary, its managers focus on different types of opportunities in the corporate entrepreneurial process. Existing literature on the attention-based view mostly notes the influence of attention structures on upper management attention, but we believe it can be applied fruitfully to middle management and reveal structural factors that determine how middle managers allocate their limited attention to different entrepreneurial opportunities that originate in lower organizational levels. 


\section{Initiative Selling and the Notion of "Policy Windows"}

The role of middle managers as initiative sellers derives largely from the issue-selling literature (e.g., Ashford, Rothbard, Piderit, \& Dutton, 1998; Dutton \& Ashford, 1993; Dutton, Ashford, O’Neill, \& Lawrence, 2001). This stream of research offers important insights into how middle managers contribute to strategy making by influencing which issues receive the attention of top management, but it also leaves some important questions unanswered. Dutton and colleagues (2001: 730) call for more research into how champions learn to make moves or determine appropriate timing for action (or inaction), with greater attention to two organizational and contextual factors: (1) patterned regularities, which indicate "how issue sellers entrain to internal and external rhythms . . . such as legal and regulatory deadlines, media events, and other patterned regularities" and (2) irregularities, or "how irregularly timed aspects of an internal organizational context (such as other issues, limited resources, and 'shocks to the system') and the external environment affect sellers' thinking and success in timing their issue-selling moves."

"Policy windows" (Kingdon, 1984), an important concept from the policy agenda-setting literature, may help address these questions. Adopting an attention-based perspective (March $\&$ Olsen, 1976) and extending it into the public policy context, Kingdon (1984) proposes a model of legislative agenda setting that highlights the role of policy windows, or agendasetting opportunities, in moving policy issues onto formal government agendas. When policy windows are open, the timing is right for policy entrepreneurs to take action to "push their pet solutions, or push attention to their special problems" (Kingdon, 1984: 166). We apply this concept to the organizational level of analysis because it offers a powerful mechanism for describing when and how middle managers sell their initiatives to top managers.

In summary, we submit that a better understanding of the strategic role of middle managers in corporate entrepreneurship requires insights from the attention-based perspective (March \& Olsen, 1976; Ocasio, 1997; Weick, 1979). In particular, by introducing attention structures (Ocasio, 1997), we attempt to recognize how middle managers' limited attention may affect their ability to discover and evaluate various opportunities. By introducing policy windows (Kingdon, 1984), we also can detail how middle managers take advantage of patterned regularities and irregularities to sell their initiatives. We thus present our two-phase model of middle managers in the corporate entrepreneurial process next.

\section{Middle Managers as Initiative Evaluators and Sellers: A Two-Phase Model}

Our model examines the impetus process by which middle managers evaluate and champion entrepreneurial initiatives. We propose two phases: (1) the prescreening phase, during which middle managers discover and evaluate entrepreneurial opportunities emerging from lower organizational levels and choose to sponsor some of them, and (2) the screening phase, in which middle managers sell their sponsored entrepreneurial opportunities to top managers. In the prescreening phase, attention structures regulate the limited attentional focus of middle managers to various entrepreneurial opportunities, whereas in the screening phase, 


\section{Figure 1 \\ Two-Phase Model of the Middle Management Involvement in the Corporate Entrepreneurial Process}

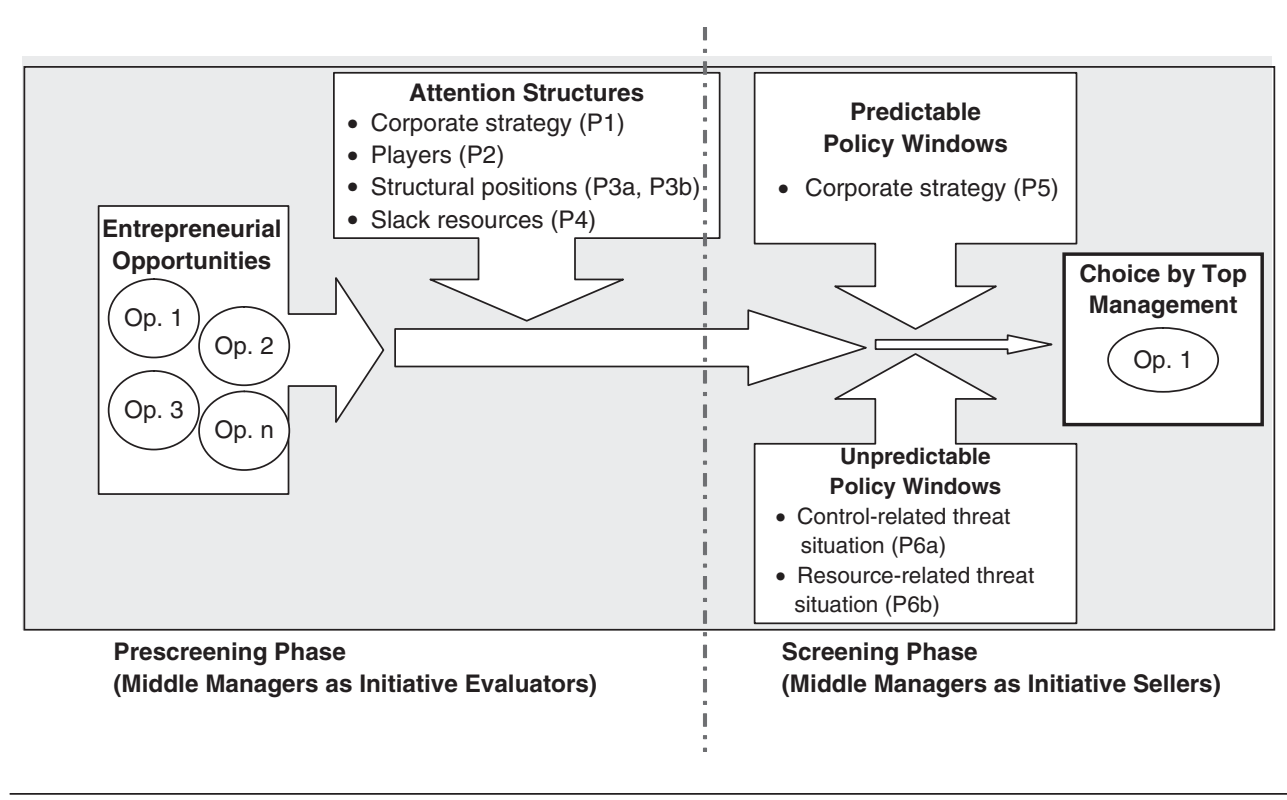

middle managers draw the attention of top management to their preferred initiatives by leveraging policy windows (Kingdon, 1984) and prompting top managers to choose among multiple initiatives. ${ }^{1}$ Figure 1 provides an illustration of our two-phase model.

Before presenting the model, we clarify our distinction between exploratory and exploitative entrepreneurial opportunities. Entrepreneurial opportunities are usually defined as opportunities to bring into existence new goods, services, raw materials, and organizing methods that allow outputs to be sold at more than their cost of production (Shane \& Venkataraman, 2000). ${ }^{2}$ Corporate entrepreneurial opportunities vary in their relatedness to core businesses and competences in terms of products, markets, or resources (Sharma \& Chrisman, 1999). For the purposes of this study, we focus on relatedness to a firm's core business and competence as an important distinguishing feature of corporate entrepreneurial opportunities or initiatives. We use the term "exploratory opportunities (initiatives)" to represent those opportunities that are unrelated or marginally related to a firm's core business and competence, whereas "exploitative opportunities (initiatives)" indicates related ones. ${ }^{3}$ This distinction reflects Burgelman's (1983b) notion of autonomous and induced strategic initiatives. According to Burgelman, most strategic activities are induced by the firm's current concept of strategy (e.g., new product development projects for existing business), but autonomous strategic activities that lie outside the scope of the current concept of strategy also emerge. Thus, autonomous strategic initiatives provide the basis for exploratory innovations, whereas induced strategic initiatives lead to exploitative innovations (Burgelman, 1983b). 


\section{The Prescreening Phase}

In this phase, middle managers prescreen the entrepreneurial opportunities that exist in the organization and determine which opportunities to give impetus to. With limited time and attentional capacities (March \& Olsen, 1976; Simon, 1947), they notice only a subset of the entrepreneurial opportunities. Selective attention to entrepreneurial opportunities varies with the organization's attention structures, which include four broad categories of attention regulators: rules of the game, players, structural positions, and resources (Ocasio, 1997). These four regulators jointly influence the allocation of middle managers' attention among entrepreneurial opportunities, especially exploratory versus exploitative ones.

Rules of the game. The rules of the game are "the formal and informal principles of action, interaction, and interpretation that guide and constrain decision makers in accomplishing the organization's tasks and in obtaining social status, credits, and rewards in the process" (Ocasio, 1997: 196). Embodied in a set of norms, values, and beliefs shared by organizational actors, the rules of the game offer the logic of action that guides the formulation of strategic interests and decisions in organizations (Thornton \& Ocasio, 1999).

For a given firm, the rules of the game become manifest in its strategic orientation. In one of the most widely cited typologies, Miles and Snow (1978) identify four strategy types: prospectors, analyzers, defenders, and reactors. We focus on prospectors and defenders, as significant differences exist between these two strategy types on the entrepreneurial dimension. ${ }^{4}$ Prospectors, who emphasize the development of new markets and the provision of new products or services, routinely take externally rather than internally directed actions. In contrast, defenders focus on defending their domains, produce a limited set of products directed at narrow market segments, and tend not to search outside their domains for new opportunities.

A firm's strategic orientation regulates the attention of middle managers through three mechanisms. One is the use of management control systems. These systems are formalized routines and procedures that use information to maintain or alter patterns in organizational activity (Simons, 1987). ${ }^{5}$ Management controls in defender firms tend to place a greater emphasis on financial measures such as short-term budgets, whereas those in prospector firms place more weight on nonfinancial criteria such as new product development, market share, and R\&D (Ittner, Larcker, \& Rajan, 1997; Langfield-Smith, 1997; Simons, 1987). Another mechanism is the implementation of recruiting strategies that attract, develop, and retain managers with the appropriate skill mix. Prospector organizations pursue managers who are externally oriented and focus on pioneering new products and technologies and developing new markets. In contrast, defender organizations pursue managers who are internally oriented and primarily work to improve the efficiency of existing operations (Miles \& Snow, 1978; Taylor \& Giannantonio, 1993). A third mechanism is the development of knowledge structures, which are mental templates employed by managers to facilitate information processing and focus their attention on the most important elements of the organizational environment (Walsh, 1995). Managers who follow different strategies attend to specific, relatively well-specified strategic elements that lead to knowledge structures aligned with their strategic types. The development of such knowledge structures, in turn, helps focus 
managers' attention on certain types of problems that are consistent with their strategic types (Kabanoff \& Brown, 2008).

To the extent that management control systems, recruiting strategies, and knowledge structures are developed in line with a firm's strategic orientation, middle managers' attention likely is directed toward some entrepreneurial initiatives and away from others. In particular, in a firm with a prospector strategy, middle managers tend to pay more attention to exploratory initiatives that depart from the norm; in one with a defender strategy, they likely pay more attention to exploitative initiatives. Although empirical evidence about how strategic types influence the attention of middle managers is sparse, our expectation seems consistent with Floyd and Wooldridge's (1992) finding that a defender strategy reduces the demand for innovative offerings championed by middle managers, whereas a prospector strategy encourages middle managers to champion a constant stream of initiatives. It also resonates with Burgelman's (1983b) observation that prospector organizations emphasize autonomous strategic activities, whereas defender organizations emphasize induced strategic behavior. Thus, we offer the following proposition:

Proposition 1: A firm's strategic orientation influences middle managers' attention to exploratory initiatives. Specifically, middle managers in prospector organizations are more likely to notice exploratory initiatives, whereas middle managers in defender organizations are more likely to notice exploitative initiatives.

Players. The key players in the corporate entrepreneurial process usually include operationlevel product champions, middle-level organizational champions (or sponsors), and top managers. Because the influence of product champions is more salient than that of top managers during the prescreening phase, we focus on product champions and their discretionary role in directing middle managers' attention toward certain entrepreneurial opportunities.

Product champions are organizational members who create, define, or adopt an idea for a technological innovation and are willing to assume significant risk to implement the innovation (Maidique, 1980: 64). Product-championing activities are necessary to "turn a new idea into a concrete new project in which technical and marketing development could begin to take shape" (Burgelman, 1983c: 232). These activities are usually performed at the level of frontline managers (e.g., group leaders or venture managers). Product champions, especially influential ones, play a key role in producing entrepreneurial opportunities. Some scholars note that champions are more likely to be involved with exploratory opportunities (Chandy \& Tellis, 1998; Ettlie, Bridges, \& O'Keefe, 1984; Schon, 1963); others find that champions are involved equally with exploratory and exploitative technology and product ideas (Markham \& Griffin, 1998). Because exploratory opportunities usually have longer life cycles and entail higher technological and market uncertainties, it may be more difficult to recognize exploratory opportunities than exploitative ones (Leifer, O’Connor, \& Rice, 2001). In the absence of product champions, therefore, the chance for middle managers to attend to an exploratory opportunity tends to be lower than in the case of an exploitative opportunity.

Proposition 2: In the absence of a product champion, middle managers are less likely to notice exploratory initiatives than exploitative initiatives. 
Structural positions. Structural positions refer to "the roles and social identifications that specify (a) the functions and orientations of decision-makers, and (b) their interrelationships with other structural positions internal and external to the firm" (Ocasio, 1997: 197). Prior research notes that the structural positions of middle managers influence the extent to which they play their strategic roles in the strategy process (Shi et al., 2009). Here we consider two aspects of structural positions relevant to middle managers: whether middle managers are located in a corporate venture unit and whether they hold boundary-spanning positions.

To allocate organizational attention to various aspects of the organization's environment (Lawrence \& Lorsch, 1967), firms develop specialized units and departments. This specialization allows organizational members to focus their attention on their own tasks and ignore the activities of other units. A distinct corporate venture unit, for example, is controlled by the parent firm and responsible for investing in new business opportunities (Block \& MacMillan, 1993; Burgelman, 1984; Hill \& Birkinshaw, 2008). ${ }^{6}$ The unit isolates the entrepreneurial processes from the main organization, which gives corporate entrepreneurs more flexibility to act but still maintain connections with the parent firm (Hoskisson \& Busenitz, 2001).

Although middle managers are constantly subject to the influence of a firm's strategic orientation during the prescreening phase, the corporate venture unit provides a buffer against the dominant logic of the firm. Corporate venture units are widely noted for their exploratory roles; they focus on the development of new opportunities and competencies rather than the exploitation of existing competencies. Whereas managers in a typical business unit likely attempt to exploit existing firm capabilities, a corporate venture unit encourages them to look outside existing business logics and explore new opportunities that may seem unrelated to mainstream activities (Keil, 2002). Therefore, a venture unit creates a new organization within the organization, in which people develop new sets of norms, values, and beliefs that could diverge from established ways of doing things. In other words, a venture unit may foster the development of a new set of rules of the game at the venture unit level, which frees middle managers from their preoccupation with the current business and competency of the firm and directs their attention to initiatives that depart from the conventional.

Following this view, we posit that middle managers in a corporate venture unit may be buffered from the influence of the firm's strategic orientation. Because they are influenced by new rules of the game at the venture unit level that emphasize exploration, these middle managers attend more to exploratory entrepreneurial initiatives than do those in other units.

Proposition 3a: Middle managers in a corporate venture unit are more likely to notice exploratory initiatives than are middle managers in other units.

Middle managers in boundary-spanning positions (e.g., sales, marketing, R\&D) have connections both across organizational units and outside of the organization and therefore a better position from which to sense changes in the external environment and track the latest market and technical developments (Floyd \& Wooldridge, 1997). By directing their attention to new information, resources, and technologies that are not available to other middle managers, these connections increase the chances of spotting exploratory opportunities that are not apparent to non-boundary-spanning managers. 
Some empirical evidence supports this reasoning. Hutt, Reingen, and Ronchetto (1988) find that middle managers with boundary-spanning roles (e.g., marketing) are more likely than non-boundary-spanning managers to conceive of new business opportunities outside the organization's mainstream. Kleinbaum and Tushman (2007) find that the network ties of middle managers across divisional boundaries facilitate the discovery of autonomous innovations that cross the lines of business. In a study of technology acquisitions, Graebner (2004) finds that managers who have responsibilities that span organizational boundaries (i.e., for activities, functions, or strategies that encompass the acquired firm and components of the acquiring firm) can spot opportunities for unanticipated value creation. Pappas and Wooldridge (2007: 324) also indicate that boundary-spanning middle managers tend to engage in more divergent strategic activities, "activities that challenge the 'dominant logic' of the firm, help organizations enter new markets, and spark the development of new capabilities." Therefore, we expect that middle managers in boundary-spanning positions pay more attention to exploratory initiatives than do their non-boundary-spanning counterparts.

Proposition 3b: Middle managers who hold boundary-spanning positions are more likely to notice exploratory initiatives than are middle managers who do not hold such positions.

Resources. A number of scholars suggest that an organization's capacity to engage in corporate entrepreneurial activity is constrained by its resource base (Covin \& Slevin, 1991; Hisrich \& Peters, 1986; Hornsby, Naffziger, Kuratko, \& Montagno, 1993). In particular, slack resources, or "the pool of resources in an organization that is in excess of the minimum necessary to produce a given level of organizational output" (Nohria \& Gulati, 1996: 1246), are critical (Bourgeois, 1981; Cyert \& March, 1963; Pfeffer \& Salancik, 1978). Among their various effects on organizations, levels of slack resources may affect the ability of managers to focus on exploratory entrepreneurial initiatives. March and Shapira (1992) state that slack resources serve to direct managerial attention on the advantages, rather than the dangers, of greater innovation and experimentation. Empirical evidence reveals that slack promotes experimentation with new strategies, ideas, and projects that otherwise would not be approved (e.g., Burgelman, 1991; Burgelman \& Sayles, 1986; Singh, 1986).

Nohria and Gulati (1996) recognize that slack has an inverse U-shaped effect on innovation through two underlying mechanisms: Slack fosters both greater experimentation and diminishing discipline with regard to innovative projects. When the level of slack is too low, managerial attention tends to be preoccupied with short-term performance issues rather than with long-term, innovative projects. As slack increases, it frees managerial attention (Cyert \& March, 1963) and fosters innovation. Yet when the level of slack becomes too high, it inhibits innovation by fostering complacency and lax controls. Accordingly, an intermediate level of slack might be optimal for organizational innovation. Following Nohria and Gulati, we expect a curvilinear relationship between slack resources and middle managers' attention to exploratory initiatives, such that the likelihood that middle managers attend to an exploratory initiative first increases and then decreases as slack increases.

Proposition 4: Up to a certain point, higher levels of slack resources are associated with greater likelihood of middle managers' noticing exploratory initiatives; beyond that point, the association is negative. 
The foregoing discussion delineates the influence of various attention regulators (i.e., rules of the game, players, structural positions, and slack resources) on middle managers' selective attention to certain entrepreneurial opportunities during the prescreening phase. After middle managers discover an opportunity and provide the necessary support to nurture it into a nascent business venture, the next step entails gaining the attention of top managers to exploit the opportunity, as we discuss next.

\section{The Screening Phase}

Having survived the prescreening phase and become a nascent business venture, an initiative needs additional impetus before it can receive the necessary corporate resources for further exploitation. During the screening phase, middle managers "go to bat" for their sponsored initiatives. Top managers then screen these initiatives and select some for further exploitation. A firm's attention structures not only channel the attentional focus of top managers who evaluate and legitimize existing initiatives (Ocasio, 1997) but draw middle managers' attention away from or toward championing activity by signaling upper managers' receptivity to new projects (Barnett, 2008).

Middle managers are not just passive recipients of these attention signals. Rather, we posit that middle managers take advantage of policy windows - patterned organizational regularities and irregularities - to deal with or perhaps dismantle existing attention structures. We define a policy window as a situation in which middle managers receive prompting, from an internal or external event, to take proactive action to push their sponsored initiatives onto the corporate agenda. There are two types of policy windows. "Predictable policy windows" are more institutionalized and occur more frequently, such that their openings and closings are more predictable to managers. "Unpredictable policy windows" instead are more random and occur less frequently (Howlett, 1998; Kingdon, 1984).

Predictable policy windows. Also referred to as "institutionalized choice opportunities" (Christensen, 1976), predictable policy windows refer to events such as weekly staff meetings, quarterly strategy meetings, annual corporate budget reviews, and so on. They are predictable in that they entail recurrent procedural events. Because the windows are predictable and usually initiated by the firm, both top and middle managers can plan for their opening in advance of their actual occurrence. Furthermore, these routine events likely create "business as usual" conditions that motivate managers to rely on their habitual tendencies to guide their interpretation and behavior (Louis \& Sutton, 1991). Therefore, when facing predictable situations, managers likely adopt established rules of the game and restrict the range of opportunities that they consider.

In turn, we expect that reliance on established rules of the game privileges opportunities that fit with the firm's current strategic orientation. To the extent that an opportunity fits better with the firm's strategic orientation, it may earn favor among top managers, which increases the likelihood it will be chosen for further exploitation. As indicated in the discussion of the prescreening phase, top managers in a prospector firm likely pay more attention to exploratory 
initiatives that depart from a conventional approach, unlike top managers in a defender firm, who tend to focus their attention on exploitative initiatives.

Because they can anticipate top managers' tendency to pick initiatives, middle managers with exploratory initiatives are likely to adjust their initiative-selling strategies accordingly. In a field study of the evolution of Intel's corporate strategy, Burgelman (1991) observes that champions tend to fit their initiatives to the scope of an organization's strategy rather than challenging it. For example, when selling the RISC (reduced instruction set computing) processor, which fell outside Intel's deliberate corporate strategy, the champion disguised the product as a coprocessor rather than a stand-alone processor. Dutton and colleagues (2001) also argue that the sale of exploratory initiatives is more likely to succeed when the sellers tone down and package the innovation as exploitative, though they do not consider the possible influence of strategic types.

We extend these arguments and suggest a modified proposition: When a predictable window opens, middle managers tend to package their initiatives to conform to the strategic orientation of their organization. In organizations that emphasize a defender strategy, middle managers with exploratory initiatives tend to package their initiatives as exploitative, but in organizations that emphasize a prospector strategy, those who want to sell exploratory initiatives instead package their initiatives as even more exploratory.

Proposition 5: Predictable policy windows prompt middle managers in prospector organizations to package their exploratory initiatives as exploratory. Middle managers in defender organizations are more likely to package their exploratory initiatives as exploitative.

Unpredictable policy windows. Unpredictable policy windows result from unexpected, nonroutine events, such as technological shocks (Schumpeter, 1934; Tushman \& Anderson, 1986) and environmental jolts (Meyer, 1982; Sine \& David, 2003). Also labeled "triggering events" (Shapero, 1984; Stopford \& Baden-Fuller, 1994) or "strategic surprises" (Ansoff, 1975; Dutton \& Duncan, 1987), these moments "create high levels of uncertainty and threaten or are perceived to threaten an organization's high priority goals" (Seeger, Sellnow, \& Ulmer, 1998: 233).

The uncertain and threatening nature of unpredictable policy windows generates a strong sense of urgency because it delivers the clear message that "business as usual" no longer exists. An effective response to such events can earn top managers substantial idiosyncrasy credits; conversely, failure to respond in a timely manner can lead to a potential legitimacy crisis for top managers and threaten their base of organizational power and control (Dutton, 1986, 1988). Top managers are therefore motivated to switch their cognitive gears from "habits of minds" to "active thinking" (Louis \& Sutton, 1991). They begin to reexamine the effectiveness and appropriateness of their established ways of doing things and implement important changes in organizational strategy and structure, if necessary.

Unpredictable policy windows often take the form of environmental jolts, "transient perturbations whose occurrences are difficult to foresee and whose impacts on organizations are disruptive and often inimical" (Meyer, 1982: 515). They may lead to drastic changes in the dominant logic of the firm or industry; for example, Sine and David (2003) find that 
environmental jolts induced a higher level of entrepreneurial activity in the U.S. electricity industry by delegitimizing existing institutional logics. The energy crisis of the 1970s opened an unpredictable policy window to allow for a challenge to the dominant logic that considered electric power the only way to fulfill U.S. energy demands. The resulting recognition of electricity as just one of many methods created more entrepreneurial opportunities.

These urgent, threatening policy windows may be perceived as "a negative situation in which loss is likely and over which one has relatively little control" (Dutton \& Jackson, 1987: 80; italics in original), which should evoke some organizational response. Yet two bodies of literature predict opposite responses to such a threat perception: Prospect theory (Kahneman \& Tversky, 1979) anticipates a risk-seeking response, whereas the threat-rigidity thesis (Staw, Sandelands, \& Dutton, 1981) suggests a risk-averse response. To reconcile these predictions, George, Chattopadhyay, Sitkin, and Barden (2006) propose that the notion of threat in prospect theory relates to a potential loss of tangible resources (e.g., a likely loss of resources due to a competitor launching a new product), whereas the notion of threat in the threat-rigidity thesis pertains to a potential loss of control (e.g., a regulatory body issues a new regulation harmful to the organization, leading to a more controlling environment).

In keeping with this suggestion, we separate threatening situations generated by unpredictable policy windows into two broad categories of threat perceptions: resource-related threats and control-related threats. According to the threat-rigidity thesis, in a control-related threat situation, top managers embrace the status quo, reduce participation, and increase centralized decision making (Dutton \& Jackson, 1987), as well as avoid strategic change actions (Thomas, Clark, \& Gioia, 1993), which implies they retain, rather than alter, their organizational strategy. In response to such a threat situation, both defender and prospector organizations tend to adopt familiar, well-known patterns of action, though "the direction of the responses will vary with the strategy emphasized" (Chattopadhyay, Glick, \& Huber, 2001: 941). For example, prospector organizations become even more likely to pursue externally directed actions (e.g., opening new market niches, offering new products or services), whereas defenders increase their tendency to pursue internally directed actions.

Consistent with the threat-rigidity thesis, we expect that in response to control-related threats, top managers pay more attention to entrepreneurial opportunities that fit the firm's core strategy. Top managers in prospector organizations focus on exploratory initiatives; top managers in defender organizations consider exploitative initiatives. To increase their odds of success, middle managers in turn will adjust their initiative selling behavior to promote exploratory initiatives to their prospector organizations but exploitative initiatives to their defender organizations.

Proposition 6a: When an unpredictable policy window is perceived as a control-related threat situation, middle managers in prospector organizations likely sell exploratory initiatives, whereas middle managers in defender organizations likely sell exploitative initiatives.

In response to a resource-related threat situation, prospect theory predicts that top managers will be risk seeking and consider novel, risky alternatives rather than well-established solutions and routines. The prospect of loss, such as a rapid decline of performance, due to changes in technologies or market needs, may motivate the organization to develop new 
knowledge and capabilities (Nonaka, 1994; Winter, 2000). Similarly, we argue that such situations prompt top managers' dissatisfaction with the dominant logic of action and trigger dramatic changes in the organizational strategy. However, firms that adopt different strategies may differ in their responses to this trigger. Holmqvist (2004) suggests that a sense of dissatisfaction with prevailing rules may cause a predominantly exploitative organization to enter an exploratory process, including experimentation and trial, rather than the exploitative process of routinization and repetition, whereas the opposite may be true for a predominantly exploratory organization.

We therefore expect that in response to rule-breaking situations, top managers may pay attention to opportunities that otherwise would not appear on their radar screens, that is, entrepreneurial initiatives with a lesser degree of fit with the firm's mainstream business and core strategy. Top managers in prospector organizations may pay attention to exploitative initiatives, whereas top managers in defender organizations may note exploratory initiatives. In anticipation of these tendencies, middle managers will adjust their initiative selling behavior accordingly and promote the initiatives that top managers are more likely to favor, according to the newly set rules. We submit the following proposition:

Proposition 6b: When an unpredictable policy window is perceived as a resource-related threat situation, middle managers in prospector organizations likely sell exploitative initiatives, whereas middle managers in defender organizations likely sell exploratory initiatives.

\section{Discussion}

This study makes several significant contributions to literatures on corporate entrepreneurship and middle management. First, we argue that middle managers actively participate in the "thinking" of strategy by playing two distinctive roles, namely, evaluating and selling entrepreneurial initiatives in the impetus process. Their role as initiative evaluators involves noticing a set of entrepreneurial opportunities emerging from lower organizational levels, assessing their potential for future corporate growth, making decisions about whether to endorse them, and determining how much support to offer. Their seller role instead involves leveraging contextual factors to get top management's attention and support on certain opportunities, reshaping the strategic thinking of top management, and getting top management to modify existing corporate strategy.

Second, prior middle management and championing literatures often have focused on the frequency or intensity of middle managers' championing activities but failed to distinguish among such activities in terms of their strategic importance. This study adds to existing research by emphasizing the nature, rather than the extent, of middle managers' championing activities. In other words, we are uninterested in the frequency or intensity of championing activities and rather are concerned with the distinction between championing exploratory opportunities that are unrelated (or only marginally related) to core businesses and competences and championing exploitative opportunities. We believe this conceptualization is useful for capturing the strategic importance of each opportunity championed by middle managers. In turn, it sheds new light on how the fundamental challenge of balancing "creating the future" 
against "protecting the core" manifests itself in middle managers" responses to exploratory versus exploitative opportunities during the corporate entrepreneurial process.

Third, and perhaps most important, we extend the emerging body of literature on the strategic role of middle managers by relating it to the management of attention in a corporate entrepreneurial process. Building on the notion of attention structures, we demonstrate how middle managers discover, evaluate, sponsor, and sell entrepreneurial initiatives — particularly exploratory ones - to top management. Whereas current research derived from the attentionbased view largely focuses on upper management, we extend the discussion to middle management and discuss how attention structures direct the attentional focus of these middle managers to different entrepreneurial opportunities in the organization. Entrepreneurial opportunities proceed through a double-screening process in our model: Before being formally evaluated and screened by top managers, each opportunity is informally prescreened by middle managers. Presumably, many new and promising business opportunities never even reach the corporate context because middle managers' limited attention affects their ability to notice and sponsor them or because they perceive the chances of support from the organization as minimal. In other words, attention mechanisms operate even before any direct decision making by top managers begins.

Fourth, we go beyond the static construct of attention structures and add dynamic and timing components to our model by introducing the notion of "policy windows" from political science literature. The emergence of regular and irregular events shapes existing attention structures and affects middle managers' opportunity-selling efforts. This explanation enriches our understanding of the possible mechanisms by which middle managers sell entrepreneurial initiatives (particularly exploratory ones) to top management. We argue that predictable policy windows create situations that tend to reinforce the established rules of the game, whereas unpredictable policy windows generate situations that may challenge those established rules. These different contingencies that result influence how middle managers sell entrepreneurial initiatives (again, particularly exploratory ones) to top management. For example, middle managers can take advantage of unpredictable policy windows to convince top managers that the current corporate strategy needs to change to accommodate promising new product and business developments.

Practitioners can also draw important lessons from our discussion of the strategic role of middle managers in the corporate entrepreneurial process. First, if the strategic contributions of middle managers in corporate entrepreneurship are important to the organization, top managers should be aware of a trend in which the number of managers occupying this role has diminished considerably in larger organizations due to downsizing and restructuring in recent decades. The rationale for ridding themselves of middle managers was to cut overhead costs and increase competitiveness. But in many cases, the expected gains failed to materialize; the organizations suffered from reduced morale, motivation, and expertise on the part of surviving employees (Armstrong-Stassen, 2005; Gandolfi, 2008). Our study suggests yet another way in which the elimination of middle management may hurt organizations: In light of middle managers' strategic role for developing a diversified portfolio of entrepreneurial opportunities, their absence might jeopardize a firm's ability to explore and extend the boundaries of its capabilities. 
Second, our two-phase model informs managerial practice. We propose that though the strategic role of middle managers is constrained by the attention structures of the organization, they are not merely passive recipients of attention signals. In particular, our discussion of predictable and unpredictable policy windows suggests possible ways for middle managers to sell their entrepreneurial initiatives more effectively to top managers by turning existing attention structures to their advantage or even dismantling those attention structures. For example, when a predictable policy window opens in a defender organization, middle managers who want to sell exploratory initiatives can package their initiatives to conform to the strategic orientation of their organization, that is, as exploitative, to increase their odds of success. The opposite is true when a predictable policy window opens in a prospector organization.

\section{Future Research Directions}

We identify three important areas for future research: (1) attention structures, (2) policy windows, and (3) characteristics of a firm's external environment.

\section{Attention Structures}

Future research could further explore the nuances of how each of the attention regulatorsrules, players, structural positions, and resources - influences middle managers' attention to different types of entrepreneurial opportunities (particularly those exploratory ones). For example, our study focused on strategic orientation as a manifestation of a firm's rules of the game. Yet another source for the generation of rules is the organization's historical precedents (Ocasio, 1997). Organizations often make decisions on the basis of lessons they have learned from prior experiences. When they repeat a specific action over time, they develop routines and competencies (Burgelman, 1983b; Levitt \& March, 1988), which define the set of businesses the organization should be in and opportunities it attends to. As such, this tendency to rely on historical precedents might lead to learning traps that hinder the creation of breakthrough inventions in established firms (Ahuja \& Lampert, 2001). Research thus might investigate how reliance on historical precedents directs middle managers' attention to or away from exploratory opportunities.

With regard to players, researchers could consider the relationship between middle managers' characteristics (e.g., values, functional background, tenure, etc.) and their attention to opportunities. In particular, researchers might further examine whether and how prior organizational experience (and champion experience in particular) directs middle managers' attention to certain opportunities. Are middle managers who have championed exploratory opportunities in the past more likely to notice exploratory initiatives than are middle managers without such experience? Is an exploratory opportunity more likely to survive the prescreening and screening phases when the middle manager serves as both product champion and organizational champion (Day, 1994), or does it have a better chance when the two roles are played by separate individuals? 
In addition, because top management is a key determinant of strategic decisions and organizational outcomes (Finkelstein \& Hambrick, 1996; Hambrick \& Mason, 1984), scholars should examine the relationship between various top management characteristics and the middle management attention to opportunities. For example, research shows that a transformational leadership style is conducive to pursuing radical innovation, whereas a transactional leadership style facilitates the use of existing knowledge and leads to incremental innovation (Jansen, Vera, \& Crossan, 2009). How might top managers' leadership styles shape the attention of middle managers toward certain opportunities? In particular, to what extent does a transformational leadership style foster the development of an organizational culture that directs middle managers' attention to exploratory opportunities?

\section{Policy Windows}

In this study, we introduced the notion of predictable and unpredictable policy windows to discuss how middle managers take advantage of patterned regularities and irregularities to sell exploratory initiatives. Additional research could provide a more sophisticated understanding of policy windows from the three angles described below. First, in terms of unpredictable policy windows, we discussed the opposing effects of resource-related and control-related threats. However, whether a threat is resource related or control related is a matter of managerial interpretation and perception: A situation might be perceived by some managers as a resource-related threat but by others as a control-related threat. Instead of being perceived as a threat, the same situation might even be perceived as a control-enhancing opportunity (e.g., an aspect of the environment becomes less controlling due to deregulation) or an opportunity for likely gains (e.g., the potential to gain resources as a result of a new market opening up for the firm; Chattopadhyay et al., 2001).

For example, in a study of conventional newspapers' responses to digital publishing (a disruptive innovation), Gilbert (2005) notes that the newspapers studied vary in their threat perceptions: Some consider the Internet a control-reducing threat, some others consider it a resource-related threat, and still others consider it an opportunity. As another example, consider airline deregulation in the late 1970s. Deregulation might have been perceived as an opportunity by those startup airlines that exploited lower personnel costs and terminal overhead while cherry-picking high-margin routes now thrown open to entry. Yet it might have been perceived as a resource-related threat by the so-called legacy airlines that existed prior to deregulation, because it threatened their revenue streams (and hence the resources): These airlines had developed elaborate route systems, made heavy investment in terminal facilities, and absorbed higher labor costs under union contracts; such former assets lost value or even became liabilities with the advent of price competition. Thus, to the extent that managerial perceptions affect choices and actions (Cho \& Hambrick, 2006; Hambrick \& Mason, 1984; Thomas et al., 1993), how would divergent perceptions of the same situation lead to variations in middle managers' selling behavior? ${ }^{7}$

Second, in terms of predictable policy windows, executive turnovers and their implications for middle managers' selling behavior deserve further attention. In particular, extensive research has examined the impact of internal versus external successions (e.g., Wiersema, 1992). More radical strategic reorientations appear to require "outsiders," who often come in with a 
mandate to challenge the existing rules of the game that may hinder innovation. Thus, one might speculate that, when a top executive from outside the firm comes on board, middle managers may be more likely to sell exploratory initiatives. More research is needed to confirm this expectation.

In addition, our discussion is based on the presumption that policy windows are exogenous to middle managers in that these windows are introduced by either recurrent procedural events or environment shocks. Future research should explore the possibility that some policy windows may be created or "enacted" (Weick, 1979) by middle managers to promote an initiative that would otherwise be ignored by top management. Middle management champions might enact policy windows with some regularity (e.g., by arranging for meetings with top management) rather than waiting for one to "open" for some other reason-predictable or unpredictable. It follows that rather than initiatives flocking to a window when it opens, sometimes windows will open in response to an entrepreneurial initiative.

\section{External Environment}

Although we have touched on the influence of external contingencies in our discussion of unpredictable policy windows, a firm's external environment is largely left out of our two-phase model. Further research could investigate environmental settings that might affect middle managers' attention to entrepreneurial opportunities. For example, environmental dynamism - the perceived instability and continuing changes in a firm's markets (Keats \& Hitt, 1988) - likely directs middle managers' attention to exploratory or exploitative opportunities through its influence on attention structures. Our study suggests that a firm's strategic orientation influences middle managers' attention to exploratory opportunities, but this proposed relationship might be moderated by environmental dynamism. In a more dynamic environment, middle managers in prospector organizations are even more likely to notice exploratory opportunities. In addition, firms in a dynamic environment likely have lower levels of slack resources (Simsek, Veiga, \& Lubatkin, 2007), which might lead to more middle management attention to exploitative rather than exploratory opportunities.

Environmental dynamism might also influence middle managers' initiative selling behavior by determining the frequency and types of policy windows that occur in the organization. In a more dynamic environment, for example, more resource-related threat situations might occur as rival firms launch new products at a faster rate (Miller, 1987). Increased dynamism also opens more market opportunities and triggers firms to develop more radically new products (Zahra \& Bogner, 2000). More research is needed on the relationship between environmental dynamism and the frequency and types of policy windows.

We summarize our recommendations in Table 1.

\section{Conclusion}

We have examined attention-based effects on the strategic behavior of middle managers in the corporate entrepreneurial process. We thus offer explanations of how a firm's attention structures influence the entrepreneurial initiatives middle managers choose to notice and 


\section{Table 1}

\section{Summary of Recommendations for Research}

\begin{tabular}{|c|c|c|}
\hline Recommendations & Directions & Examples \\
\hline $\begin{array}{l}\text { Recommendation 1: } \\
\text { Attention structures }\end{array}$ & $\begin{array}{l}\text { Rules of the game: Investigating the } \\
\text { role of historical precedents in } \\
\text { directing middle managers' attention } \\
\text { Players: Further exploring the } \\
\text { relationship between middle } \\
\text { management characteristics and } \\
\text { middle management attention } \\
\text { Players: Further exploring the } \\
\text { relationship between top management } \\
\text { characteristics and middle } \\
\text { management attention }\end{array}$ & $\begin{array}{l}\text { Do historical precedents direct middle } \\
\text { managers' attention away from } \\
\text { exploratory opportunities? } \\
\text { Are middle managers with prior experience } \\
\text { in championing exploratory initiatives } \\
\text { more likely to notice exploratory } \\
\text { opportunities? } \\
\text { How does transformational leadership style } \\
\text { influence middle managers' attention to } \\
\text { exploratory opportunities? }\end{array}$ \\
\hline $\begin{array}{c}\text { Recommendation 2: } \\
\text { Policy windows }\end{array}$ & $\begin{array}{l}\text { Unpredictable policy windows: } \\
\text { Investigating the influence of } \\
\text { managerial perceptions of threat and } \\
\text { opportunity situations on middle } \\
\text { managers' selling behavior } \\
\text { Predictable policy windows: Further } \\
\text { examining the influence of predictable } \\
\text { windows } \\
\text { Exogenous vs. enacted policy windows: } \\
\text { Investigating the differential effects of } \\
\text { exogenous and enacted windows on } \\
\text { middle managers' selling behavior }\end{array}$ & $\begin{array}{l}\text { How do divergent perceptions of the same } \\
\text { situation lead to variations in middle } \\
\text { managers' selling behavior? How does it } \\
\text { change middle managers' selling behavior } \\
\text { if an unpredictable policy window is } \\
\text { perceived as a control-enhancing } \\
\text { opportunity instead of a resource-related } \\
\text { threat, or vice versa? } \\
\text { Are middle managers more likely to sell } \\
\text { exploratory initiatives upon the arrival of } \\
\text { an outside executive? } \\
\text { Under what conditions do middle managers } \\
\text { enact policy windows to sell exploratory } \\
\text { opportunities? }\end{array}$ \\
\hline $\begin{array}{l}\text { Recommendation 3: } \\
\text { External environment }\end{array}$ & $\begin{array}{l}\text { Further investigating environmental } \\
\text { settings that affect middle managers' } \\
\text { initiative evaluation and selling } \\
\text { behavior }\end{array}$ & $\begin{array}{l}\text { How does environmental dynamism affect } \\
\text { middle managers' attention through its } \\
\text { influence on attention structures? } \\
\text { How does environmental dynamism } \\
\text { determine the frequency and types of } \\
\text { policy windows that occur in the } \\
\text { organization? }\end{array}$ \\
\hline
\end{tabular}

sponsor, as well as how middle managers leverage various types of policy windows, whether to turn existing attention structures to their advantage or to dismantle those attention structures in their efforts to sell their chosen initiatives to top management. Finally, we have identified useful avenues for further research. We hope this proposed framework helps stimulate additional scholarly discussion pertaining to this exciting line of research.

\section{Notes}

1. For the purpose of our study, we present two separate phases through which entrepreneurial opportunities travel in a sequential order. It should be noted that the actual corporate entrepreneurial process is often more complex and idiosyncratic than what is proposed here. For instance, sometimes the corporate entrepreneurial process might 
assume certain features of a garbage can process (March \& Olsen, 1976), where entrepreneurial opportunities do not preexist but are "created" by acts of human imagination (Sarasvathy, Dew, Velamuri, \& Venkataraman, 2003).

2. This conceptualization of entrepreneurial opportunity is reflective of a dominant view that opportunities are discovered - that is, they exist independent of entrepreneurs. Another view asserts that opportunities are created rather than found (Ardichvili, Cardozo, \& Ray, 2003). A middle-ground position holds that some opportunities are discovered and others are created (Alvarez \& Barney, 2007; Short, Ketchen, Shook, \& Ireland, 2010).

3. Note that we conceptualize exploratory and exploitative opportunities in a manner corresponding to some definitions of exploratory and exploitative innovations. Jansen, Van den Bosch, and Volberda (2006), for example, define exploratory innovations as radical innovations that are designed to meet the needs of emerging customers or markets and that require new knowledge or departure from existing knowledge (see also Danneels, 2002). Consistent with such definitions, exploratory and exploitative opportunities can be understood as opportunities that, if pursued, may lead to explorative and exploitative innovations. However, all of the opportunities may not eventually translate into actual innovations.

4. Analyzers exhibit characteristics of both prospectors and defenders. Reactors do not follow a coherent strategy and are often viewed as an instance of strategy absence (Inkpen \& Choudhury, 1995).

5. Management control systems include formalized information-based processes for planning, budgeting, cost control, environmental scanning, competitor analysis, performance evaluation, resource allocation, and employee rewards (Simons, 1987).

6. There are two typical subtypes of venture units: internal ones, which focus on opportunities identified within the organization, and external ones, which focus on opportunities external to the organization (Birkinshaw \& Hill, 2005; Hill \& Birkinshaw, 2008). Although both subtypes of venture units are likely to pursue some combination of exploratory and exploitative activities (Hill \& Birkinshaw, 2008), external venture units tend to focus more on exploration and less on exploitation (Dushnitsky \& Lenox, 2005; Keil, 2002; Keil, Autio, \& George, 2008).

7. This paragraph owes much to one of the anonymous reviewers of this journal, to whom we are grateful.

\section{References}

Ahuja, G., \& Lampert, C. M. 2001. Entrepreneurship in the large corporation: A longitudinal study of how established firms create breakthrough inventions. Strategic Management Journal, 22: 521-543.

Alvarez, S. A., \& Barney, J. B. 2007. Discovery and creation: Alternative theories of entrepreneurial action. Strategic Entrepreneurship Journal, 1: 11-26.

Angle, H. L. 1989. Psychology and organizational innovation. In A. H. Van de Ven, H. L. Angle, \& M. S. Poole (Eds.), Research on the management of innovation: 135-170. New York: Harper \& Row.

Ansoff, I. 1975. Managing strategic surprise by response to weak signals. California Management Review, 18(2): 21-33.

Ardichvili, A., Cardozo, R., \& Ray, S. 2003. A theory of entrepreneurial opportunity identification and development. Journal of Business Venturing, 18: 105-123.

Armstrong-Stassen, M. 2005. Coping with downsizing: A comparison of executive-level and middle managers. International Journal of Stress Management, 2: 117-141.

Ashford, S. J., Rothbard, N. P., Piderit, S. K., \& Dutton, J. E. 1998. Out on a limb: The role of context and impression management in selling gender-equity issues. Administrative Science Quarterly, 43: 23-67.

Barnett, M. L. 2008. An attention based view of real options reasoning. Academy of Management Review, 33: 606-628.

Barringer, B. R., \& Bluedorn, A. C. 1999. The relationship between corporate entrepreneurship and strategic management, Strategic Management Journal, 20: 421-444.

Birkinshaw, J., \& Hill, S. A. 2005. Corporate venturing units: Vehicles for strategic success in the new Europe. Organizational Dynamics, 34: 247-257.

Block, Z., \& MacMillan, I. C. 1993. Corporate venturing. Boston: Harvard Business School Press.

Bourgeois, L. J., III. 1981. On the measurement of organizational slack. Academy of Management Review, 6: 29-39.

Bower, J. 1970. Managing the resource allocation process. Homewood, IL: Irwin.

Burgelman, R. A. 1983a. Corporate entrepreneurship and strategic management: Insights from a process study. Management Science, 29: 1349-1364. 
Burgelman, R. A. 1983b. A model of the interaction of strategic behavior, corporate context, and the concept of strategy. Academy of Management Review, 8: 61-70.

Burgelman, R. A. 1983c. A process model of internal corporate venturing in the diversified major firm. Administrative Science Quarterly, 28: 223-244.

Burgelman, R. A. 1984. Designs for corporate entrepreneurship in established firms. California Management Review, 26: 154-166.

Burgelman, R. A. 1991. Intraorganizational ecology of strategy making and organizational adaptation: Theory and field research. Organization Science, 2: 239-262.

Burgelman, R. A., \& Sayles, L. R. 1986. Inside corporate innovation: Strategy, structure, and managerial skills. New York: Free Press.

Burgelman, R. A., \& Välikangas, L. 2005. Managing internal corporate venturing cycles. MIT Sloan Management Review, 46(4): 26-34.

Chandy, R. K., \& Tellis, G. L. 1998. Organizing for radical product innovation: The overlooked role for willingness to cannibalize. Journal of Marketing Research, 35: 474-487.

Chattopadhyay, P., Glick, W. H., \& Huber, G. P. 2001. Organizational actions in response to threats and opportunities. Academy of Management Journal, 44: 937-955.

Cho, T. S., \& Hambrick, D. C. 2006. Attention as the mediator between top management team characteristics and strategic change: The case of airline deregulation. Organization Science, 17: 453-469.

Christensen, C. C. 2000. The innovator's dilemma. New York: HarperCollins.

Christensen, S. 1976. Decision making and socialization. In J. G. March \& J. P. Olsen (Eds.), Ambiguity and choice in organizations: 351-385. Bergen, Norway: Universitesforlaget.

Covin, J. G., \& Miles, M. P. 1999. Corporate entrepreneurship and the pursuit of competitive advantage. Entrepreneurship Theory and Practice, 23: 47-64.

Covin, J. G., \& Slevin, D. P. 1991. A conceptual model of entrepreneurship as firm behavior. Entrepreneurship Theory and Practice, 16: 7-25.

Cyert, R. M., \& March, J. G. 1963. A behavioral theory of the firm. Englewood Cliffs, NJ: Prentice-Hall.

Danneels, E. 2002. The dynamics of product innovation and firm competences. Strategic Management Journal, 23 : 1095-1121.

Day, D. L. 1994. Raising radicals: Different processes for championing innovative corporate ventures. Organization Science, 5: 148-172.

Dess, G. G., Ireland, R. D., Zahara, S. A., Floyd, S. W., Janney, J. I., \& Lane, P. J. 2003. Emerging issues in corporate entrepreneurship. Journal of Management, 29: 351-378.

Dushnitsky, G., \& Lenox, M. J. 2005. When do firms undertake R\&D by investing in new ventures? Strategic Management Journal, 26: 947-965.

Dutton, J. E. 1986. The processing of crisis and non-crisis strategic issues. Journal of Management Studies, 23 : 510-517.

Dutton, J. E. 1988. Understanding strategic agenda building and its implications for managing change. In L. R. Pondy, R. J. Boland Jr., \& H. Thomas (Eds.), Managing ambiguity and change: 127-144. New York: Wiley.

Dutton, J. E., \& Ashford, S. J. 1993. Selling issues to top management. Academy of Management Review, 18: $397-428$.

Dutton, J. E., Ashford, S. J., O’Neill, R. M., \& Lawrence, K. A. 2001. Moves that matter: Issue selling and organizational change. Academy of Management Journal, 44: 716-736.

Dutton, J. E., \& Duncan, R. B. 1987. The creation of momentum for change through the process of strategic issue diagnosis. Strategic Management Journal, 8: 279-295.

Dutton, J. E., \& Jackson, S. E. 1987. Categorizing strategic issues: Links to organizational action. Academy of Management Review, 12: 76-90.

Ettlie, J. E., Bridges, W. P., \& O’Keefe, R. D. 1984. Organization strategy and structural differences for radical versus incremental innovation. Management Science, 30: 682-695.

Finkelstein, S., \& Hambrick, D. C. 1996. Strategic leadership: Top executives and their effects on organizations. New York: West.

Floyd, S. W., \& Wooldridge, B. 1992. Middle management involvement in strategy and its association with strategic type: A research note. Strategic Management Journal, 13(Special Issue): 53-168.

Floyd, S. W., \& Wooldridge, B. 1994. Dinosaurs or dynamos? Recognizing middle management's strategic role. Academy of Management Executive, 8(4): 47-57. 
Floyd, S. W., \& Wooldridge, B. 1997. Middle management's strategic influence and organizational performance. Journal of Management Studies, 34: 465-485.

Floyd, S. W., \& Wooldridge, B. 1999. Knowledge creation and social networks in corporate entrepreneurship: The renewal of organizational capability. Entrepreneurship Theory and Practice, 23: 123-143.

Fulop, L. 1991. Middle managers: Victims or vanguards of the entrepreneurial movement? Journal of Management Studies, 28: 25-44.

Gandolfi, F. 2008. Learning from the past: Downsizing lessons for managers. Journal of Management Research, 8: 3-17.

George, E., Chattopadhyay, P., Sitkin, S. B., \& Barden, J. 2006. Cognitive underpinnings of institutional persistence and change: A framing perspective. Academy of Management Review, 31: 347-385.

Gilbert, C. G. 2005. Beyond resource allocation: How definition and impetus interact to shape strategic outcomes. In J. L. Bower \& C. G. Gilbert (Eds.), From resource allocation to strategy: 269-295. New York: Oxford University Press

Graebner, M. 2004. Momentum and serendipity: How acquired leaders create value in the integration of technology firms. Strategic Management Journal, 25: 751-777.

Guth, W. D., \& Ginsberg, A. 1990. Guest editor's introduction: Corporate entrepreneurship. Strategic Management Journal, 11(Special Issue): 5-15.

Hambrick, D. C., \& Mason, P. A. 1984. Upper echelons: The organization as a reflection of its top managers. Academy of Management Review, 9: 193-206.

Hill, S. A., \& Birkinshaw, J. 2008. Strategy-organization configurations in corporate venture units: Impact on performance and survival. Journal of Business Venturing, 23: 423-444.

Hisrich, R. D., \& Peters, M. P. 1986. Establishing A new business venture unit within a firm. Journal of Business Venturing, 1: 307-322.

Hitt, M. A., Ireland, R. D., Camp, S. M., \& Sexton, D. L. 2001. Strategic entrepreneurship: Entrepreneurial strategies for wealth creation. Strategic Management Journal, 22: 479-491.

Hitt, M. A., Ireland, R. D., Camp, S. M., \& Sexton, D. L. 2002 (Eds.). Strategic entrepreneurship: Creating a new integrated mindset. Oxford, UK: Blackwell.

Holmqvist, M. 2004. Experiential learning processes of exploitation and exploration within and between organizations: An empirical study of product development. Organization Science, 15: 70-81.

Hornsby, J. S., Kuratko, D. F., \& Zahra, S. A. 2002. Middle managers' perception of the internal environment for corporate entrepreneurship: Assessing a measurement scale. Journal of Business Venturing, 17: 253-273.

Hornsby, J. S., Naffziger, D. W., Kuratko, D. F., \& Montagno, R. V. 1993. An interactive model of the corporate entrepreneurship process. Entrepreneurship Theory and Practice, 17: 29-37.

Hoskisson, R. E., \& Busenitz, L. W. 2001. Market uncertainty and learning distance in corporate entrepreneurship entry mode choice. In M. A. Hitt, R. D. Ireland, S. M. Camp, \& D. L. Sexton (Eds.), Strategic entrepreneurship: Creating a new integrated mindset: 151-172. Oxford, UK: Blackwell.

Howlett, M. 1998. Predictable and unpredictable policy windows: Institutional and exogenous correlates of Canadian federal agenda-setting. Canadian Journal of Political Science, 31: 495-524.

Hutt, M. D., Reingen, P. H., \& Ronchetto, J. R. 1988. Tracing emergent processes in marketing strategy formation. Journal of Marketing, 52: 4-19.

Inkpen, A., \& Choudhury, N. 1995. The seeking of strategy where it is not: Towards a theory of strategy absence. Strategic Management Journal, 16: 313-323.

Ittner, C. D., Larcker, D. F., \& Rajan, M. V. 1997. The choice of performance measures in annual bonus contract. Accounting Review, 2: 231-256.

Jansen, J. J. P., Van den Bosch, F. A. J., \& Volberda, H. W. 2006. Exploratory innovation, exploitative innovation, and performance: Effects of organizational antecedents and environmental moderators. Management Science, 52: 1661-1674.

Jansen, J. J. P., Vera, D., \& Crossan, M. 2009. Strategic leadership for exploration and exploitation: The moderating role of environmental dynamism. Leadership Quarterly, 20: 5-18.

Kabanoff, B., \& Brown, S. 2008. Knowledge structures of prospectors, analyzers, and defenders: Content, structure, stability, and performance. Strategic Management Journal, 29: 149-171.

Kahneman, D., \& Tversky, A. 1979. Prospect theory: An analysis of decision under risk. Econometrica, 47: 263-292. 
Kanter, R. M. 1983. The change masters. New York: Basic Books.

Keats, B., \& Hitt, M. 1988. A causal model of linkages among environmental dimensions, macro organizational characteristics, and performance. Academy of Management Journal, 31: 570-598.

Keil, T. 2002. External corporate venturing: Strategic renewal in rapidly changing industries. Westport, CT: Quorum.

Keil, T., Autio, E., \& George, G. 2008. Corporate venture capital, disembodied experimentation and capability development. Journal of Management Studies, 45: 1475-1505.

King, A. W., Fowler, S. W., \& Zeithaml, C. P. 2001. Managing organizational competencies for competitive advantage: The middle-management edge. Academy of Management Executive, 15: 95-106.

Kingdon, J. W. 1984. Agendas, alternatives, and public policies. Boston: Little, Brown.

Kleinbaum, A. M., \& Tushman, M. L. 2007. Building bridges: The social structure of interdependent innovation. Strategic Entrepreneurship Journal, 1: 103-122.

Kuratko, D. F., Ireland, R. D., Covin, J. G., \& Hornsby, J. S. 2005. A model of middle-level managers' entrepreneurial behavior. Entrepreneurship Theory and Practice, 29: 699-716.

Langfield-Smith, K. 1997. Management control systems and strategy: A critical review. Accounting, Organizations and Society, 22: 207-232.

Lawrence, P. R., \& Lorsch, J. W. 1967. Organization and environment. Homewood, IL: R.D. Irwin.

Leifer, R., O’Connor, G. C., \& Rice, M. 2001. Implementing radical innovation in mature firms: The role of hubs. Academy of Management Executive, 15: 102-113.

Levinthal, D.A., \& March, J.G. 1993. The myopia of learning. Strategic Management Journal, 14(Special Issue): 95-113.

Levitt, B., \& March, J. G. 1988. Organizational learning. Annual Review of Sociology, 14: 319-340.

Louis, M. R., \& Sutton, R. I. 1991. Switching cognitive gears: From habits of mind to active thinking. Human Relations, 44: 55-76.

Maidique, M. A. 1980. Entrepreneurs, champions, and technological innovation. MIT Sloan Management Review, 21(2): 59-76.

March, J. G., \& Olsen, J. P. 1976. Ambiguity and choice in organizations. Bergen, Norway: Universitesforlaget.

March, J. G., \& Shapira, Z. 1992. Variable risk preferences and the focus of attention. Psychological Review, 99: $172-183$.

Markham, S., \& Griffin, A. 1998. The breakfast of champions: Associations between champions and product development environments, practices, and performance. Journal of Product Innovation Management, 15: 436-454.

Meyer, A. D. 1982. Adapting to environmental jolts. Administrative Science Quarterly, 27: 515-538.

Miles, R. E., \& Snow, C. C. 1978. Organizational strategy, structure and process. New York: McGraw-Hill.

Miller, D. 1987. The structural and environmental correlates of business strategy. Strategic Management Journal, 8: $55-76$.

Mintzberg, H. 1989. Mintzberg on management. New York: Free Press.

Noda, T., \& Bower, J. L. 1996. Strategy making as iterated processes of resource allocation. Strategic Management Journal, 17(Special Issue): 159-192.

Nohria, N., \& Gulati, R. 1996. Is slack good or bad for innovation? Academy of Management Journal, 39: 1245-1264.

Nonaka, I. 1994. A dynamic theory of organizational knowledge creation. Organizational Science, 5: 14-37.

Ocasio, W. 1997. Toward an attention-based view of the firm. Strategic Management Journal, 18(Special Issue): 187-206.

Pappas, J. M., \& Wooldridge, B. 2007. Middle managers' divergent strategic activity: An investigation of multiple measures of network centrality. Journal of Management Studies, 44: 323-341.

Pfeffer, J., \& Salancik, G. R. 1978. The external control of organizations: A resource dependence perspective. New York: Harper \& Row.

Sarasvathy, S. D., Dew, N., Velamuri, S. R., \& Venkataraman, S. 2003. Three views of entrepreneurial opportunity. In Z. J. Acs \& D. B. Audretsch (Eds.), Handbook of entrepreneurship research: 141-160. Norwell, MA: Kluwer Academic.

Schon, D. A. 1963. Champions of radical new inventions. Harvard Business Review, 41: 77-86.

Schumpeter, J. 1934. The theory of economic development. Cambridge, MA: Harvard University Press.

Seeger, M. W., Sellnow, T. L., \& Ulmer, R. R. 1998. Communication, organization and crisis. In M. E. Roloff (Ed.), Communication yearbook (Vol. 21): 231-275. Thousand Oaks, CA: Sage. 
Shane, S., \& Venkataraman, S. 2000. The promise of entrepreneurship as a field of research. Academy of Management Review, 26: 217-226.

Shapero, A. 1984. The entrepreneurial event. In C. A. Kent (Ed.), The environment for entrepreneurship: 21-40. Lexington, MA: D. C. Heath.

Sharma, P., \& Chrisman, J. J. 1999. Toward a reconciliation of the definition in the field of corporate entrepreneurship. Entrepreneurship Theory and Practice, 23: 11-27.

Shi, W., Markoczy, S. L., \& Dess, G. G. 2009. The role of middle management in the strategy process: Group affiliation, structural holes, and tertius iungens. Journal of Management, 35: 1453-1480.

Short, J. C., Ketchen, D. J., Shook, C. L., \& Ireland, R. D. 2010. The concept of “opportunity” in entrepreneurship research: Past accomplishments and future challenges. Journal of Management, 36: 40-65.

Simon, H. A. 1947. Administrative behavior: A study of decision-making processes in administrative organizations. Chicago: Macmillan.

Simons, R. 1987. Accounting control systems and business strategy: An empirical analysis. Accounting, Organizations and Society, 12: 357-374.

Simsek, Z., Veiga, J., \& Lubatkin, M. 2007. The impact of managerial environmental perceptions on corporate entrepreneurship: Toward understanding discretionary slack's pivotal role. Journal of Management Studies, 44: 1398-1424.

Sine, W. D., \& David, R. J. 2003. Environmental jolts, institutional change, and the creation of entrepreneurial opportunity in the US electric power industry. Research Policy, 32: 185-207.

Singh, J. 1986. Performance, slack and risk taking in organizational decision making. Academy of Management Journal, 29: 562-585.

Staw, B. M., Sandelands, L. E., \& Dutton, J. E. 1981. Threat-rigidity effects in organizational behavior: A multilevel analysis. Administrative Science Quarterly, 26: 501-524.

Stopford, J. M., \& Baden-Fuller, C. W. F. 1994. Creating corporate entrepreneurship. Strategic Management Journal, 15: 521-536.

Taylor, M. S., \& Giannantonio, C. M. 1993. Forming, adapting, and terminating the employment relationship: A review of the literature from individual, organizational, and interactionist perspectives. Journal of Management, 19: 461-515.

Thomas, J. B., Clark, S. M., \& Gioia, D. A. 1993. Strategic sensemaking and organizational performance: Linkages among scanning, interpretation, action, and outcomes. Academy of Management Journal, 36: 239-270.

Thornton, P. H., \& Ocasio, W. 1999. Institutional logics and the historical contingency of power in organizations: Executive succession in the higher education publishing industry, 1958-1990. American Journal of Sociology, 105: 801-843.

Tushman, M. L., \& Anderson, P. 1986. Technological discontinuities and organizational environments. Administrative Science Quarterly, 31: 439-465.

Utterback, J. M. 1994. Mastering the dynamics of innovation. Boston: Harvard Business School Press.

Van de Ven, A. H. 1986. Central problems in the management of innovation. Management Science, 32: 590-607.

Walsh, J. 1995. Managerial and organizational cognition: Notes from a trip down memory lane. Organization Science, 6: 280-321.

Weick, K. M. 1979. The social psychology of organizing (2nd ed.). New York: Random House.

Wiersema, M. F. 1992. Strategic consequences of executive succession within diversified firms. Journal of Management Studies, 29: 73-94.

Winter S. G. 2000. The satisficing principle in capability learning. Strategic Management Journal, 21: 981-996.

Wolpert, J. D. 2002. Breaking out of the innovation box. Harvard Business Review, 80(8): 77-83.

Zahra, S. A., \& Bogner, W. C. 2000. Technology strategy and software new ventures' performance: Exploring the moderating effect of the competitive environment. Journal of Business Venturing, 15: 135-173. 